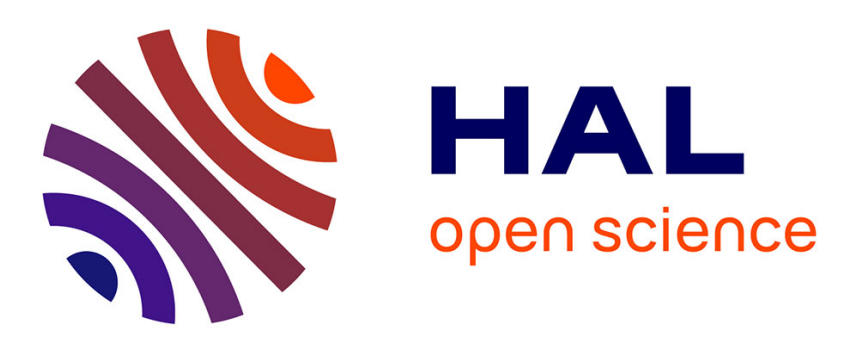

\title{
Unexpected high decomposition of legume residues in dry season soils from tropical coffee plantations and crop lands
}

Girma Abera, Endalkachew Wolde-Meskel, Lars Bakken

\section{- To cite this version:}

Girma Abera, Endalkachew Wolde-Meskel, Lars Bakken. Unexpected high decomposition of legume residues in dry season soils from tropical coffee plantations and crop lands. Agronomy for Sustainable Development, 2014, 34 (3), pp.667-676. 10.1007/s13593-013-0172-7 . hal-01234795

\author{
HAL Id: hal-01234795 \\ https://hal.science/hal-01234795
}

Submitted on 27 Nov 2015

HAL is a multi-disciplinary open access archive for the deposit and dissemination of scientific research documents, whether they are published or not. The documents may come from teaching and research institutions in France or abroad, or from public or private research centers.
L'archive ouverte pluridisciplinaire HAL, est destinée au dépôt et à la diffusion de documents scientifiques de niveau recherche, publiés ou non, émanant des établissements d'enseignement et de recherche français ou étrangers, des laboratoires publics ou privés. 


\title{
Unexpected high decomposition of legume residues in dry season soils from tropical coffee plantations and crop lands
}

\author{
Girma Abera • Endalkachew Wolde-Meskel • \\ Lars R. Bakken
}

Accepted: 18 July 2013 / Published online: 16 August 2013

(C) INRA and Springer-Verlag France 2013

\begin{abstract}
Crop residues are essential fertilizer source of lowinput farming systems in Sub-Saharan Africa. However, crop residues provide nutrients only if they decompose in the soil. Decomposition is assumed to be very low during the dry season due to the scarcity of water, but there are few quantitative knowledge on decomposition under such conditions. Therefore, we studied the decomposition of legume residues, haricot bean (Phaseolus vulgaris L.), and pigeon pea (Cajanus cajan L. (Millps) using litterbag experiments in two coffee and two crop land agroecosystems of southern Ethiopia. The residues were surface applied and subsoil buried under irrigated and non-irrigated conditions and were then retrieved after 30 180 days. We measured mass loss, decay rate constant $(k)$, and $\mathrm{C}$ and $\mathrm{N}$ concentrations. Results demonstrate an unexpected high decomposition in seasonal dry soils, even when the litterbags were placed on the soil surface. Interestingly, $89 \%$ of the initial $\mathrm{N}$ of pigeon pea and $85 \%$ of haricot bean were released after 150 days, on the average. Thus microbial decomposition is unexpectedly high during the dry season. This finding has implications for the effect of plant residues on the supply of mineral $\mathrm{N}$ to crops growing during subsequent wet season.
\end{abstract}

Keywords Dry season $\cdot$ Legume residue $\cdot$ Mass loss · Nitrogen release $\cdot$ Residue placement $\cdot$ Soil moisture

\footnotetext{
G. Abera $\cdot$ L. R. Bakken

Department of Plant and Environmental Sciences, Norwegian University of Life Sciences, P.O. Box 5003, 1432 Ås, Norway

G. Abera $(\bowtie) \cdot$ E. Wolde-Meskel

School of Plant and Horticultural Sciences, Hawassa University, P.O. Box, 05, Hawassa, Ethiopia

e-mail: girmajibat2006@yahoo.com

G. Abera

e-mail: girma.jibat@umb.no
}

\section{Introduction}

Integrated cropping of legumes and cereal crops is commonly practiced by subsistence smallholder farmers throughout the tropics (Sakala et al. 2000). In such multiple cropping systems, legume residues decomposition may provide substantial amount of nitrogen $(\mathrm{N})$ for subsequent crops. This can only be utilized effectively by the crop if the net $\mathrm{N}$ mineralization from decomposing residues is synchronized with crop growth. Such synchronization is particularly important for legume residues with a high $\mathrm{C} / \mathrm{N}$ ratio, since the mineral $\mathrm{N}$ kinetics during decomposition of such materials is characterized by a transient phase of net $\mathrm{N}$ immobilization followed by a subsequent net $\mathrm{N}$ mineralization (Borgen et al. 2011). If the transient net $\mathrm{N}$ immobilization coincides with the growth of a crop, the residues will reduce the crop yield while increasing the mineral $\mathrm{N}$ content during subsequent dry season (Abera et al. 2012).

Smallholder farmers in periodically dry tropical climates grow their crops largely during the rainy season and legume residues are available at the end of the rainy season. Thus, residue has to undergo decomposition for subsequent nutrient release during crop growth. Nevertheless, residue decomposition is expected to be low or trivial during the dry season. This is due to the notion that microbial activity is insignificant during this season. Therefore, if it is to be used as an $\mathrm{N}$ fertilizer for the subsequent crop, the residue can either be incorporated into the soil immediately, or left on the surface through the dry season and then incorporated into the soil just before planting of the next crop. In theory, this choice may be an instrument to secure synchronization of net $\mathrm{N}$ mineralization with the growth of the subsequent crop. The reason for this is that degradation rates of crop residues on the soil surface are normally assumed to be slower than those of incorporated residues for a number of reasons: one is that the surface residues easily dry up; hence, decomposition is hampered by periodical or constant low moisture content (Coppens et al. 2007). Secondly, surface 
residues may have marginal contact with soil; hence, less colonization by decomposer organisms. The decomposition of plant residues have been found to be enhanced by intimate contact with the soil (Henriksen and Breland 2002), possibly due to the transfer of mineral N (or P) from the soil in cases where the decomposition rate is limited by these components. This would imply that legume residues with low $\mathrm{N}$ contents (high $\mathrm{C} / \mathrm{N}$ ratio) should be incorporated at the onset of the dry season to secure that the transient phase of net nitrogen immobilization takes place during the dry season. Legumes with high $\mathrm{N}$ contents (low $\mathrm{C} / \mathrm{N}$ ratio), on the other hand, should be incorporated later for obvious reasons (fast residue decomposition and immediate onset of net $\mathrm{N}$ mineralization).

Climate and litter composition are thought to be the primary regulators of decomposition in terrestrial ecosystems, particularly of forest (Cusack et al. 2009), but such analyses are scarce for tropical agricultural systems such as coffee plantations and crop lands. Temperature is high throughout the year in the tropics, but precipitation shows dramatic seasonal variations (Austin and Viousek 2000). Therefore, the seasonal variation in litter decomposition rates in the tropics is probably driven by seasonality of precipitation rather than temperature (Cusack et al. 2009). Despite that many studies addressed the climatic effect (precipitation and temperature), information on the effect of soil moisture on litter decomposition under specific cropping and agroecosystems in the tropics is scarce.

Litter chemical composition has been shown to be an important driver of decomposition and nutrient release in the tropics (Arunachalam and Singh 2004). Typical litter chemical indices include $\mathrm{N}$ concentration, lignin concentration, lignin/ $\mathrm{N}$ ratio, $\mathrm{C} / \mathrm{N}$ ratio, tannin concentration and polyphenolic concentrations. The importance of tissue chemistry appear to differ for surface-mulched and subsoil-buried residue decomposition, possibly due to the differences in the microbial decomposer communities on the surface versus in the soil (Henriksen and Breland 2002; Asgharipou and Rafiei 2011).

Most decomposition studies have been conducted to evaluate the effects of residue qualities on decomposition under optimum soil moisture conditions in laboratory experiments (Salinas et al. 2011; Abera et al. 2012). Generally, residue decomposition studies and specifically the contribution of residue management interventions such as irrigation and placement effects on the rate of residue decomposition and $\mathrm{N}$ release have not been much studied in coffee plantations and crop lands of tropical climates. Therefore, the objective of this study was to measure residue decomposition under natural conditions of such tropical agricultural ecosystems. We were specifically interested in determining the rate of decomposition of residues during the dry season, as affected by placement on the soil surface versus placement in the soil, irrigation versus nonirrigation and residue type (quality).

\section{Materials and methods}

\subsection{Description of study sites}

The study was conducted at four sites, Yirgalem (site $1,6^{\circ} 45^{\prime} \mathrm{N}$ and $38^{\circ} 43^{\prime} \mathrm{E}$ ), Wondo Genet (site $2,6^{\circ} 6^{\prime} \mathrm{N}$ and $38^{\circ} 28^{\prime} \mathrm{E}$ ), Awassa (site $3,6^{\circ} 3^{\prime} \mathrm{N}$ and $38^{\circ} 38^{\prime} \mathrm{E}$ ), and Ziway (site 4, $6^{\circ} 56^{\prime} \mathrm{N}$ and $38^{\circ} 7^{\prime} \mathrm{E}$ ) of southern Ethiopia, during two consecutive years (2010-2011). Hereafter, the study years, 2010 and 2011 , will be considered as year 1 and year 2, respectively. The long-term annual rain fall of site 1 was $1,216 \mathrm{~mm} \mathrm{year}^{-1}$, while $1,105 \mathrm{~mm} \mathrm{year}^{-1}$ with site $2,952 \mathrm{~mm}$ year ${ }^{-1}$ with site 3 , and $650 \mathrm{~mm}$ year $^{-1}$ with site 4 . The average daily temperature was $18.7,19.4,19.4$, and $24.0^{\circ} \mathrm{C}$, for sites 1,2 , 3, and 4 , respectively. The altitude of the study sites ranges from 1,643 to $1,950 \mathrm{~m}$ a.s.l. Sites 1,2 , and 3 were characterized by subhumid agroclimatic conditions, while site 4 was known for its semiarid climate condition.

The study sites were different regarding soil types, vegetation, and climate conditions (Fig. 1). For instance, sites 1 and 2 were under shaded coffee agroforestry systems (consisting coffee and diverse shade trees). Often, grass and other vegetations grow under the coffee canopy. On the other hand, sites 3 and 4 (crop lands) have been used for annual crops for decades. During the study years, the crop land plots (sites 3 and 4) were fallowed (i.e., no plants). The soils of the three sites (sites 2, 3, and 4) represent tropical Andosol (FAO 1998), whereas that of site 1 represents tropical Alfisol (FAO 1998). The Andosol has been further classified by different authors under different subgroups. For instance, site 2 soil was classified by FAO (1998) as Mollic Andosol, while site 3 soil as Vitric Andosol (Abayneh et al. 2006, unpublished). Andosol is formed from the parental materials of volcanic origin during tertiary and quaternary periods of geologic time (FAO 1998) and they are relatively more fertile soils.

\subsection{Study season}

Decomposition should be low or trivial during the dry season in the tropics ascribed to the notion that microbial activity is insignificant. The study period encompasses dry and wet tropical seasons with the intent to understand the effect of drought stress on residue decomposition. The period from the beginning of December till the end of March is considered to be a dry season. The expected precipitation during this period is too low to sustain a crop, hence fields are left fallowed. However, as common for tropical climate, there is some rain during the dry season; there is no clear demarcation among seasons, expect a general classification into two broad classes, dry and wet, based on expectations. By contrast, average monthly temperature often tends to be constant across seasons 
Fig. 1 Litterbag experiment at coffee plantation (a) and crop land (b) agroecosystems in southern Ethiopia
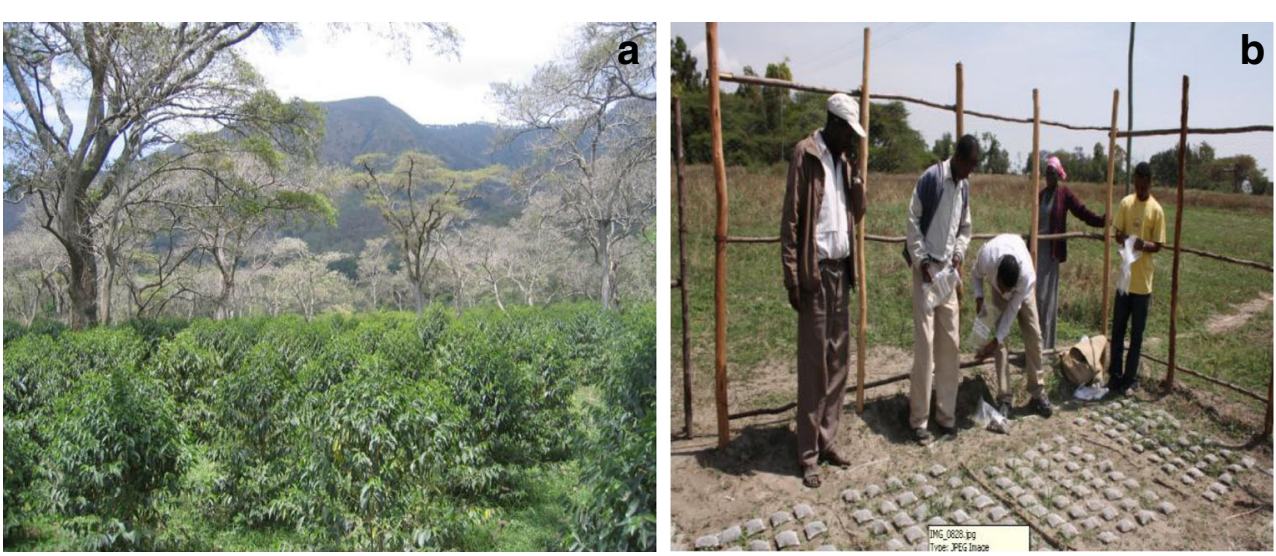

in the study sites. In both years, the experiment was carried out from December to August.

\subsection{Legume residue collection and preparation}

Legume residues including leaves, petioles, pods without seeds of haricot bean (Phaseolus vulgaris (L.), and pigeon pea, (Cajanus cajan (L.) Millps) were collected at harvesting time from Hawassa University Research and Farm Center. The different components of the plant samples were proportionally homogenized (each component was included into the samples) for litterbag experiment based on their proportion. However, the stem of pigeon pea was not included for the study due to its woody and lignified nature. The entire biomass components were proportionally homogenized prior to application. The residues were air dried and subsequently oven dried $\left(40{ }^{\circ} \mathrm{C}\right.$ for $\left.48 \mathrm{~h}\right)$. A 10 -g biomass was put in a polyvinyl net bag with a size of $10 \mathrm{~cm} \times 12 \mathrm{~cm}$ with 2 -mm size net. The total number of litter bags for each residue type and experimental site was 120 , of which 60 were placed on the surface and 60 were placed below the surface. This allowed five replicates to be taken from each treatment at each time of sampling.

\subsection{Setting litterbag experiment with legume residues}

We used standard litterbag technique (Anderson and Ingram 1993), essentially polyvinyl mesh bags $(10 \mathrm{~cm} \times 12 \mathrm{~cm})$ of 2$\mathrm{mm}$ netting. Litterbag experiments were set out on fixed plot (size of $5 \mathrm{~m} \times 5 \mathrm{~m}$ ). In general, the experiment was organized in randomized complete block design with factorial arrangement of $4 \times 2 \times 2$, four sites (sites $1,2,3$, and 4 ), two types of legume residues (haricot bean and pigeon pea) and two methods of placement (surface and subsurface). The litterbags were placed on the surface $(0 \mathrm{~cm})$ and buried $(10 \mathrm{~cm}$ deep). Since the dry season of year 1 was relatively moist, we replicated the same experiment under irrigation in one of the four sites (site 3) during the dry season of year 2 by covering the entire experimental area with a plastic roof to ensure very dry soil. This means that at this site, we had two experiments: fully irrigated and non-irrigated experiments. The irrigation was made every third day at a rate of $10 \mathrm{~L} \mathrm{~m}^{-2}(10 \mathrm{~mm})$.

Litterbags were retrieved for weight determination and $\mathrm{C}$ and $\mathrm{N}$ analyses at intervals of 30 days. The retrieved bags were cleaned of adhering soils and other (extraneous) materials, and air dried. Subsequently the residues were oven dried $\left(40{ }^{\circ} \mathrm{C}\right.$ for $48 \mathrm{~h}$ ) and reweighed to determine the amount of mass loss, and $\mathrm{C}$ and $\mathrm{N}$ in some cases.

\subsection{Soil and legume residue nutrient analyses}

The soils of the study sites $(0-15 \mathrm{~cm}$ depth) were analyzed for organic carbon, total nitrogen and available phosphorus based on standard procedures (Table 1). Soil $\mathrm{pH}$ (in $\mathrm{H}_{2} \mathrm{O}$ ) was determined in a solution of 1:2.5 soil water ratio. Soil texture was estimated by the pipette method, whereas bulk density

Table 1 Selected characteristics of coffee plantation and crop land agroecosystem soils from 0 to $15 \mathrm{~cm}$ depth in southern Ethiopia

\begin{tabular}{llllll}
\hline \multirow{2}{*}{ Parameters } & \multicolumn{2}{l}{ Coffee plantations } & & \multicolumn{2}{l}{ Crop lands } \\
\cline { 2 - 3 } \cline { 6 - 7 } \cline { 5 - 6 } & Site 1 & Site 2 & & Site 3 & Site 4 \\
\hline Clay (\%) & $55 \mathrm{a}$ & $23 \mathrm{c}$ & & $21 \mathrm{c}$ & $41 \mathrm{~b}$ \\
Silt (\%) & $26 \mathrm{~b}$ & $41 \mathrm{a}$ & & $42 \mathrm{a}$ & $42 \mathrm{a}$ \\
Sand (\%) & $19 \mathrm{~b}$ & $36 \mathrm{a}$ & & $37 \mathrm{a}$ & $20 \mathrm{~b}$ \\
$\mathrm{pH}\left(\right.$ in $\left.\mathrm{H}_{2} \mathrm{O}\right)$ & $5.6 \mathrm{c}$ & $5.9 \mathrm{c}$ & & $7.3 \mathrm{~b}$ & $8.0 \mathrm{a}$ \\
Organic C $(\%)$ & $2.26 \mathrm{~b}$ & $3.16 \mathrm{a}$ & & $1.36 \mathrm{c}$ & $2.72 \mathrm{~b}$ \\
Total N (\%) & $0.15 \mathrm{c}$ & $2.4 \mathrm{~b}$ & & $0.09 \mathrm{~d}$ & $0.30 \mathrm{a}$ \\
C/N ratio & $15 \mathrm{a}$ & $15 \mathrm{a}$ & & $13 \mathrm{~b}$ & $10 \mathrm{c}$ \\
Olsen P $\left(\mathrm{mg} \mathrm{kg}^{-1}\right)$ & $2.5 \mathrm{~d}$ & $9.5 \mathrm{c}$ & & $24.1 \mathrm{~b}$ & $43.8 \mathrm{a}$ \\
\hline
\end{tabular}

Mean values followed by different letters in a row are statistically significant different (otherwise non-significant) 
was determined by using core sampled soils by oven drying for $24 \mathrm{~h}$ at $105^{\circ} \mathrm{C}$.

Prior to chemical analyses, the oven dried residues were finely ground with Thomas-Wiley Laboratory Mill Model 4 (http://www.thomassci.com) to pass a 1-mm size sieve. The nutrient concentrations were determined only for year 1 , for budgetary reasons. Residues nutrient concentrations (carbon and nitrogen) were determined prior to litterbag setting ( 0 day) and after 30,90, and 150 days of litterbag sampling using Leco CHN-1000 analyzer. Residue phosphorous (P) concentration was determined prior field application by Olsen's method. Residue base cations such as potassium $(\mathrm{K})$, calcium $(\mathrm{Ca})$, and magnesium $(\mathrm{Mg})$ were determined (prior application) by atomic absorption spectrophotometer.

\subsection{Soil moisture determination}

Surface $(0-5 \mathrm{~cm})$ and subsurface $(10-15 \mathrm{~cm})$ soil moisture measurements were performed every 30 days from December to August on all sites during the two consecutive years (Fig. 2). The time domain reflectometry, TDR (HH2 meter with SM200 soil moisture sensor, Delta-T Devices LtD, www:http://www.delta-t.co.uk), was used for soil moisture determination. At every sampling period, 25 surface and 25 subsurface, and thus a total of 900 soil moisture measurements were performed at each site during the two study years. In addition, in year 2 a total of 2,000 daily-based surface and subsurface soil moisture measurements were performed at site 3.

\subsection{Mass loss and decomposition rate constant $(k)$}

For a rough comparison of residue decomposition rates in the different treatments, we estimated the average decay rate throughout the entire experimental period by assuming firstorder decay (Zhang et al. 2008), i.e.,

$m(t)=m(0) \times e^{-k t}$

where $m(t)$ is the amount of dry weight in the litterbag at time $=t$ and $k$ is the specific decay rate. We estimated $k$ by regression of $\ln (m(t))$ against time, where $m(t)$ is the measured dry weight at time $t$. Although $R^{2}$ values for these regressions were reasonably high (ranging from 0.66 to $0.89, p<0.0001$ ), we can assume that the rates for each time period ( 30 days) were to some extent modulated by the available water, which fluctuated throughout each experimental period (and there were gross differences between the 2 years regarding precipitation, hence soil moisture content). This was inspected by estimating $k$ for single time periods $\left(k_{\text {est }}=\ln (m(t))+\ln (m(t+1))\right)$ and plotting these values against the measured soil moisture for the same period (i.e., the average of the soil moisture contents measured at the beginning and at the end of the period; $t$ and $t+1)$.

The cumulated percentage loss of carbon, $\Delta \mathrm{C}(t)$ and nitrogen, $\Delta \mathrm{N}(t)$ from the litter bags were calculated based on measured dry weight, $m(t)$, and measured carbon and nitrogen concentration, $[\mathrm{C}](t)$ and $[\mathrm{N}](t)$.

\subsection{Statistical analyses}

The effects of sites, residue quality, residue placement, and irrigation on the rates of decomposition were examined by analyses of variance such as one-way and two-way analyses using MINITAB Software Program (MINITAB Version 14). The treatment mean differences were declared significant at $p<0.05$. The relationships between initial $\mathrm{N}$ and $\mathrm{P}$ concentrations and $\mathrm{C} / \mathrm{N}$ ratio of residue and mass loss, and their relation
Fig. 2 a-b Soil moisture contents (vol\%) of coffee plantation (site 1) and crop land (site 3) agroecosystems of southern Ethiopia determined for surface $(0-5 \mathrm{~cm})$ and subsurface $(10-15 \mathrm{~cm})$ soil layers during dry and wet seasons in years 1 and 2 . The two other sites data, sites 2 and 4 , are not presented, but showed similar trends
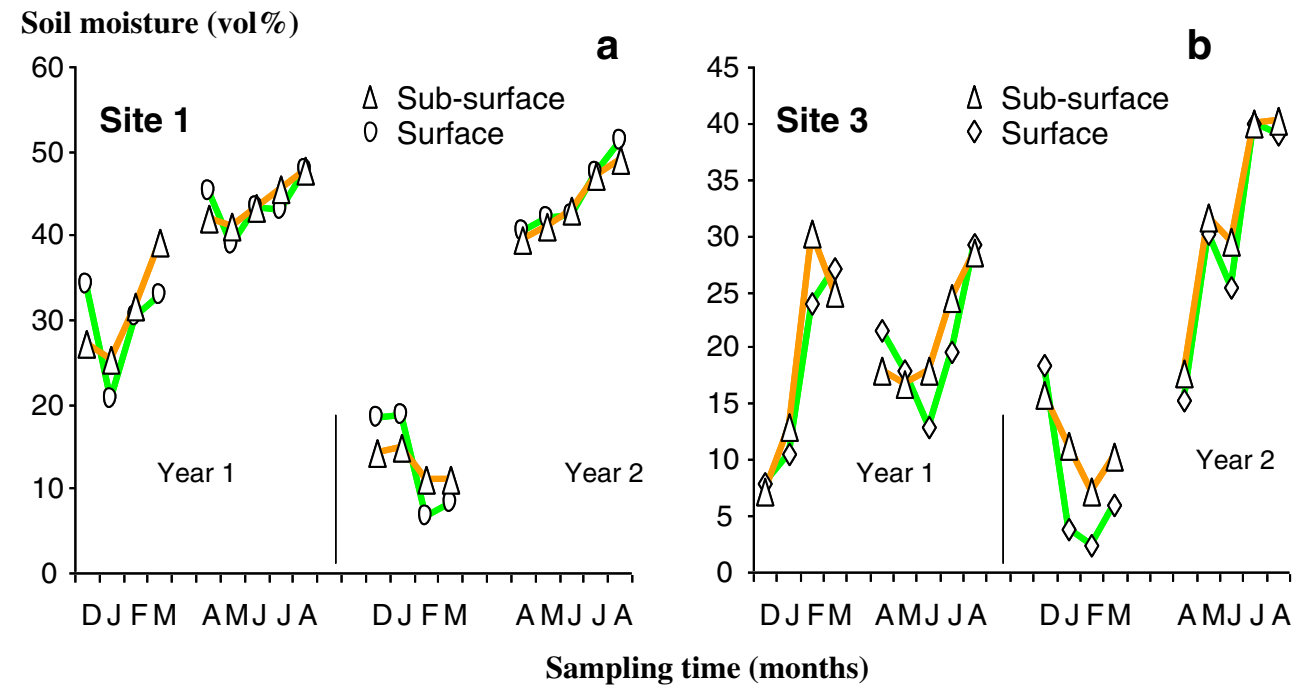

Sampling time (months) 
with $\mathrm{N}$ release were computed. The relationship between residue mass loss and soil moisture was described by linear regression analyses.

\section{Results and discussion}

\subsection{Soil and plant residue characteristics}

The bulk density and $\mathrm{pH}$ of the study sites varied significantly, and also their chemical characteristics (Table 1). Sites 1 and 2 were slightly acidic, whereas those of sites 3 and 4 are neutral to alkaline. The bulk density varied from 0.93 to $1.10 \mathrm{~g} \mathrm{~cm}^{-3}$. Sites 2 and 3 soils were loam in texture, while sites 1 and 4 were clay and silt clay loamy, respectively. These values are rated as medium to optimum for crop production.

The intensively cultivated crop land soil (site 3 ) was lower in organic carbon and total nitrogen contents than other sites, but rated as medium in terms of fertility (Landon 1991). Sites 2 and 4 soils displayed relatively higher organic carbon and total nitrogen contents, despite the fact that they were under different land uses. Apparently greater organic carbon content of site 2 soil might be ascribed to the permanent vegetation cover of coffee plants and shade trees for the last 34 years, while that of site 4 greater organic carbon and total nitrogen contents might be attributed to reduced soil organic matter decomposition due to its semiarid climate and its higher microaggregate fractions that hinder microbial access. The plant available phosphorous contents of the study soils ranged from 2.5 to $48.3 \mathrm{mg} \mathrm{kg}^{-1}$ (Olsen) that rated as deficient to optimum (Landon 1991). Specifically, sites 1 and 2 (coffee soils) exhibited lower phosphorous contents than crop land soils, which could be attributed to poor inherent phosphorous content or lack of phosphorous fertilizer input.

The legume residues, haricot bean and pigeon pea biochemical characteristics were measured before setting litterbag experiments. Haricot bean residue nutrient contents were $39.8 \%$ for $\mathrm{C}, 1.38 \%$ for $\mathrm{N}, 0.18 \%$ for $\mathrm{P}, 2.13 \%$ for $\mathrm{K}, 2.35 \%$ for $\mathrm{Ca}$, and $0.25 \%$ for $\mathrm{Mg}$. Whereas the nutrient contents of pigeon pea residue were $45.0 \%$ for $\mathrm{C}, 2.45 \%$ for $\mathrm{N}, 0.21 \%$ for $\mathrm{P}, 1.7 \%$ for $\mathrm{K}, 1.03 \%$ for $\mathrm{Ca}$, and $0.15 \%$ for $\mathrm{Mg}$. The pigeon pea residue was significantly $(p<0.0001)$ higher than haricot bean in terms of $\mathrm{C}, \mathrm{N}$, and $\mathrm{P}$ concentrations, and had low $\mathrm{C} / \mathrm{N}$ ratio, while haricot bean residue found superior in some basic cations such as $\mathrm{K}, \mathrm{Ca}$, and $\mathrm{Mg}$ concentrations.

\subsection{Soil moisture}

Temporal and spatial variations of soil moisture contents were evident, as a reflection of seasonal variation in precipitation largely between dry and wet seasons and also among sites (Fig. 2a-b). Irrespective of sites, soil moisture tended to increase in both soil layers (surface and subsurface) from December to August sampling period, and the average soil moisture content was substantially greater in wet season than in the dry season across all sites. This indicated that significant differences were displayed in soil moisture content between years, sites, and sampling months (Fig. 2a-b), as well as the interactions between site and sampling month (data not shown) at both surface and subsurface layers.

Averaged over sampling months and years, greater soil moisture content was exhibited with site 1 (32 vol\%, $\mathrm{pF} 2.5)$, while all others recorded lower average (20$21 \mathrm{vol} \%$, pF 3.75 to 3.1 ) soil moisture. While this could be primarily attributed to the higher precipitation in site 1 , variations in vegetation cover and soil high clay content at site 1 may partly play a role. Two-year-average dry-season soilmoisture content ranged from 12 to $21 \mathrm{vol} \%$ (equivalent with $\mathrm{pF} 4.9$ to 3.6), whereas the wet season average ranged from 26 to $43 \mathrm{vol} \%$ (pF 3.0 to 1.9 ). Similar soil moisture contents of an average $8 \mathrm{vol} \%$ in dry months and $39 \mathrm{vol} \%$ in wet months were reported in Afromontane forest of south-eastern Ethiopia (Yohannes et al. 2011).

\subsection{Effects of site on residue mass loss}

Averaged over residue types, placement methods, sampling days, and mass loss of legume residues were significantly $(p<0.0001)$ different among sites (Fig. 3a-d). Similar trends were observed with the other sites (data not shown). Thus, mass loss was $73 \%$ for site $1,51 \%$ for site $2,42 \%$ for site 3 , and $24 \%$ for site 4 after 30 days of sampling, irrespective of residue type and placement in year 1 , and the same trend persisted thereafter during the subsequent sampling periods. The mass loss during the first 30 days of year 2 was $30 \%$ for site $1,32 \%$ for site $2,27 \%$ for site 3 , and $17 \%$ for site 4 . As compared to the other sites (sites 2, 3 and 4), residue mass loss was significantly greater with site 1 , across the sampling days. The higher decomposition rates in site 1 could be attributed to higher microbial activity due to more favorable microclimate, mainly soil moisture. Similarly, other investigation reported greater litter decomposition in wet than mesic and dry forest condition (Singh et al. 1999) and in coffee land than in arable farm land (Teklay 2007). In the tropics, higher amplitude of fluctuation in diurnal soil temperature resulted in greater decomposition and more nitrogen mineralization than under constant soil temperature condition (Sierra 2002), though we did not record temperature in the present study.

On site 4, a few bags were destroyed by termites during year 1 but not during year 2 . The termites were evidently able to get through the mesh, and such bags with visible termite effects were not included in the determination of mass loss. However, we also occasionally observed small larvae within some of the litterbags, apparently able to enter through the 
Fig. 3 a-d Mass loss of surfaceplaced and subsoil-buried legume residues in seasonally dry coffee plantation (site 1, years 1 and 2) and crop land (site 3, years 1 and 2) agroecosystems of southern Ethiopia during two consecutive years (2010-2011) of field studies. The two other sites, sites 2 and 4 data are not presented, but showed similar trends

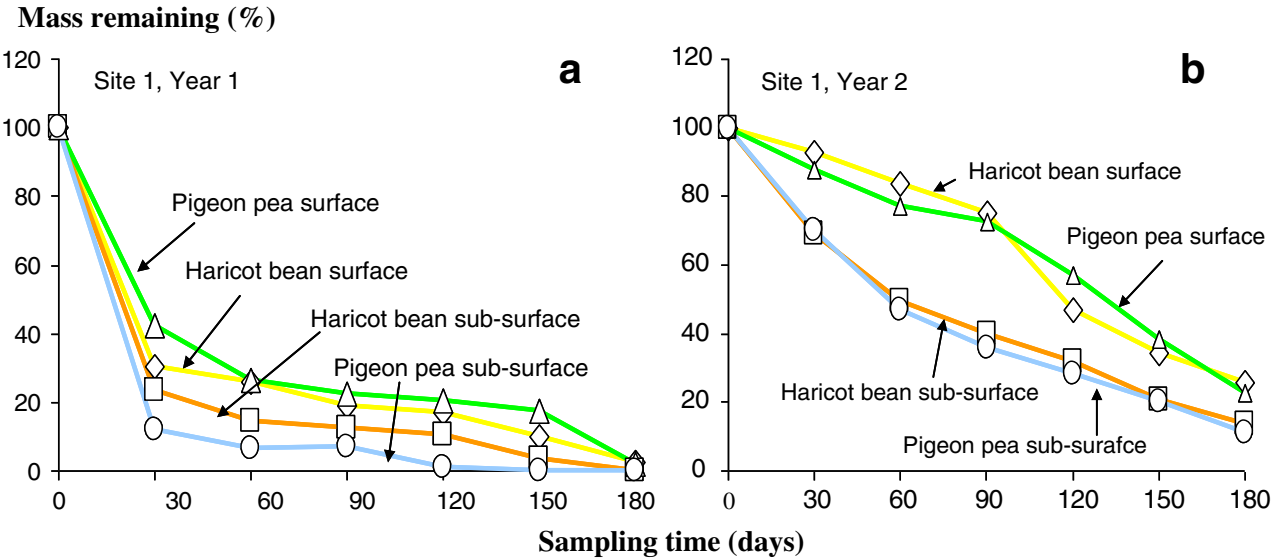

Mass remaining (\%)

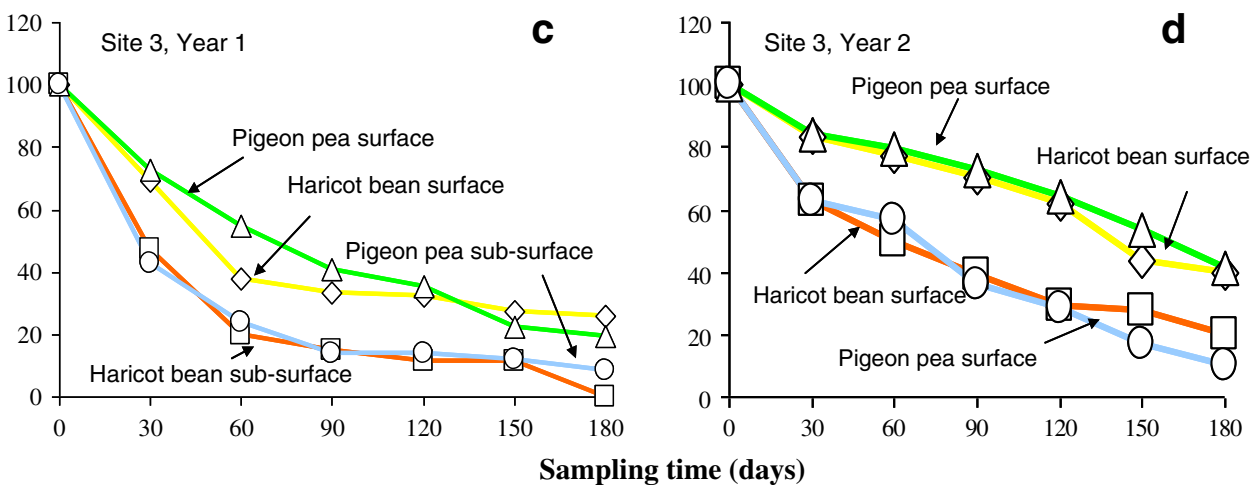

mesh and cause damage to the bags in site 2 . In another litter decomposition study, it was found that in sites where soil macro invertebrate activity is relatively high, lignin and nitrogen concentrations may not explain variations in decay rate, and the mass loss from the litterbags were partly attributed to fragmentation losses enhanced by invertebrate activity (Pouyat and Carreiro 2003).

\subsection{Effects of residue placement on mass loss}

Mass loss was faster in buried than surface-placed litterbags across all sites (Fig. 3a-d). For example, in site 1 year 1, a mass loss of 73 and $54 \%$ were recorded after 30 days subsoil burying and surface mulching treatments, respectively. Similarly, a mass loss of 47 and $36 \%$ were exhibited after 30 days of applying the same treatments, respectively, with site 1 in year 2. Moderately lower levels of mass loss were observed with sites 2 and 3 . With site 4 , the same treatments resulted in a mass loss of 27 and $22 \%$, respectively, after 30 days in year 1 , while a mass loss of 18 and $16 \%$ was displayed, respectively, in year 2 . In overall, surface applied residue mass loss was $43 \%$ lower than subsoil-buried residue in site 1 and $33 \%$ with site 4 in year 1 , after the completion of the experiment. On the other hand, the equivalent mass loss was 39 and $13 \%$, respectively, for sites 1 and 4 during year 2 .
In general, the pattern of mass loss was similar for surface applied and subsoil-buried residues across sampling days during the two study years (Fig. 3a-d). In the early phase of decomposition, high concentrations of nutrients such as nitrogen, phosphorous and sulfur in residues may exert a rateenhancing influence on mass loss of the litter that is not lignified (Coûteaux et al. 1995). In the late stage, where mainly lignified material remains, the degradation of litter is ruled by lignin mass loss, which is negatively affected by high nitrogen concentrations and positively affected by high concentrations of celluloses in the lignified material (Coûteaux et al. 1995).

The faster residue mass loss for buried than surface-placed litterbags is probably related to moisture content (surfaceplaced litterbags dry up easily on warm days, despite some moisture in the soil), although factors such as biomass-soil contact, availability of mineral nitrogen and other elements to the decomposer communities may have been of importance (Magid et al. 2006; Coppens et al. 2007). Soil moisture has been shown as the primary controlling factor of surface litter mass loss. Thus, burying/incorporation of residues may not always be necessarily important; as for example, there was slight difference in residue decomposition between surface applied and buried residues in wetter year (Y1) than drier year (Y2). Conservation-tillage systems as opposed to conventional 
tillage leads to poor residue soil contact, thereby reducing decomposition of structural plant constituents through delayed colonization by microbes and reduced availability of nutrients to microbes colonizing the residues placed on soil surface (Henriksen and Breland 2002). Foremost among other factors affecting residues decomposition, the soil moisture appeared to outweigh in the present study.

\subsection{Decomposition rate constant $(k)$}

Legume residue decomposition (mass, $\mathrm{C}$ and $\mathrm{N}$ loss) could be described reasonably well by a first-order decay function, i.e., the mass put in a litterbag exponentially declined over sampling period (Figs. 3a-d and $4 a-d$ ). This implied that single exponential decay curves described the data reasonably well $\left(R^{2}=0.60-0.89\right)$ for the entire decomposition experiment period (0-180 days) across all sites during both study years. Our results agree with the findings of Zhang et al. (2008) who stated that a first-order exponential decay function can be used to adequately describe litter decomposition process in the majority of cases. It appears important to stress that on the one hand the kinetics of our results are not perfect first-order kinetics (despite high $R^{2}$ ), but on the other hand that one could not expect these to be perfect as soil moisture and temperature were not static, naturally fluctuating through the course of time (especially soil moisture). A number of studies of forest litter decomposition proposed a two-component first-order model, in which initial litter solubility controls early rates of decomposition and more standard metrics of litter quality appear to control rates of secondary decomposition (Adair et al. 2008; Zhang et al. 2008). We could fit such a model to our data (results not shown), but considering the few time points recorded for each year (8), a two-component model would be over parameterized.

The greatest $k$ was exhibited with site 1 under both residue types and residue placement methods, while the lowest was with site 4 in both study years (results not shown). The $k$ values in the present study ranged from 0.13 to 0.65 month $^{-1}$ across sites, consistent with those previously reported values $\left(0.05-1.81 \mathrm{month}^{-1}\right)$ for tropical legumes (Dubeux et al. 2006).

3.6 Effect of residue quality on mass loss and decomposition

Haricot bean and pigeon pea residue mass loss and $k$ values were not significantly $(p<0.05)$ different (Figs. $3 \mathrm{a}-\mathrm{d}$ and $4 \mathrm{c})$, despite variations in their initial nitrogen and phosphorous concentrations and $\mathrm{C} / \mathrm{N}$ ratio (Table 1). This shows that litter quality exerts marginal control on mass loss from the litterbags, suggesting the shift in pathways of decay from microbial respiration to mass loss through leaching and loss as fine particulate matter, possibly enhanced by the activity of small invertebrates, as suggested by Pouyat and Carreiro (2003) and Zeng et al. (2010). However, in the present study rapid mass loss has occurred with both legume residues implying that they are better quality than most forest litters. Therefore, legume
Fig. 4 a-d Decay rate constant $(k$ per month) estimated as affected by irrigated versus non-irrigated (a), surface mulched and subsurface buried (b), haricot bean and pigeon pea (c), and years 1 and $2(\mathbf{d})$, based on single exponential decomposition model across seasonally dry agroecosystems in southern Ethiopia. Mean values followed by different letters between columns indicate statistically significant difference and otherwise non-significant
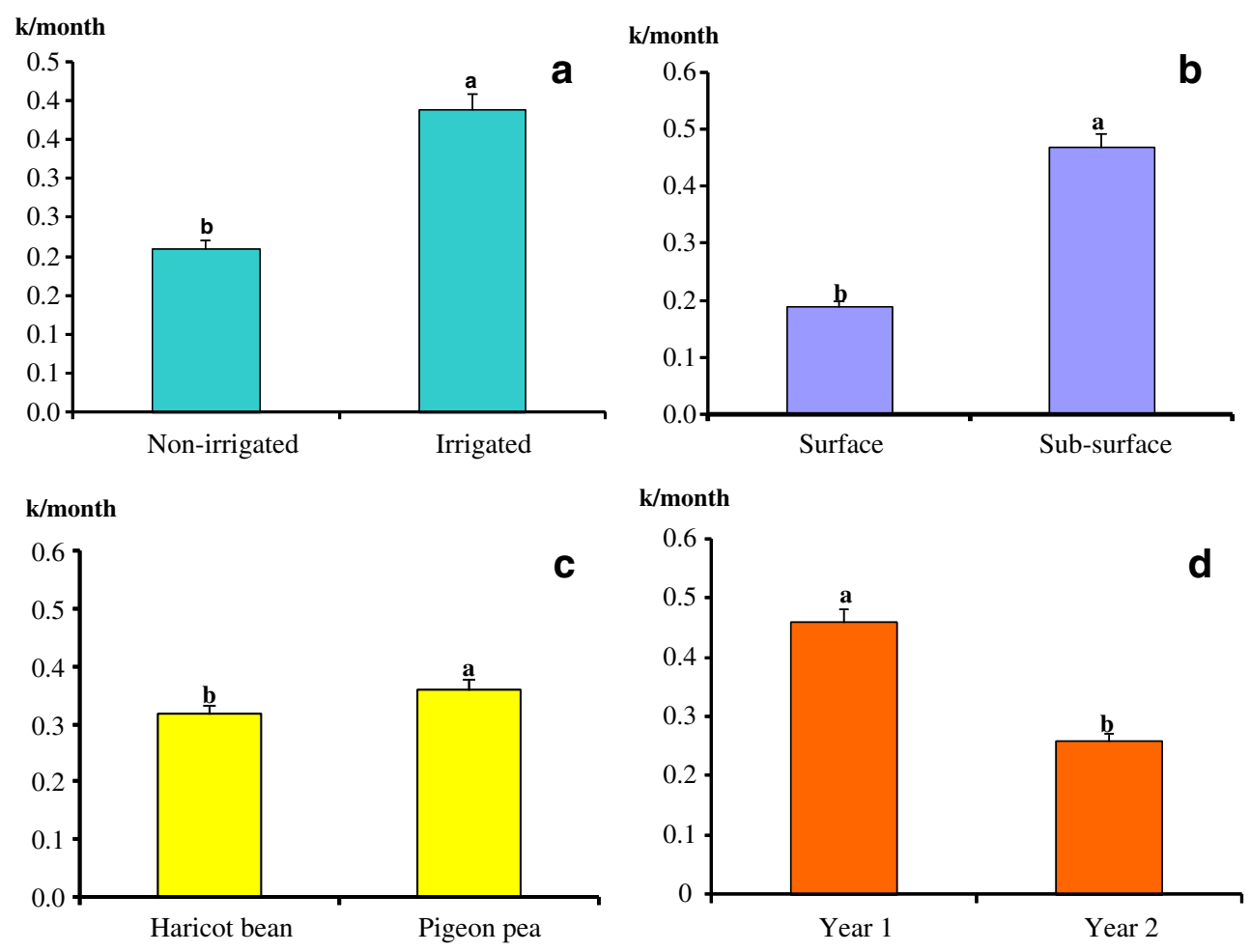

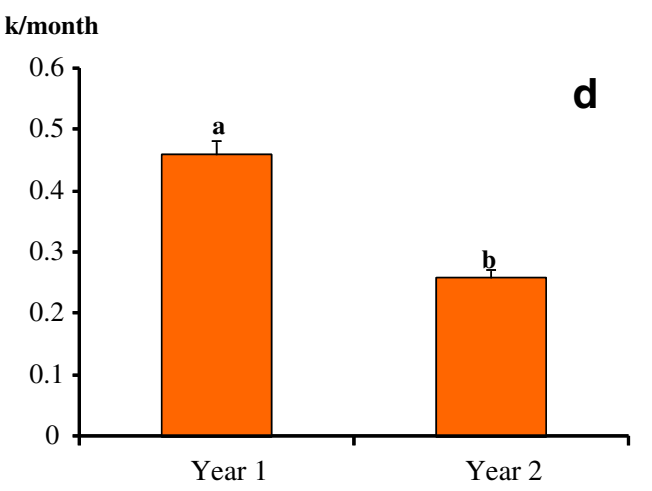


residues can be used as $\mathrm{N}$ fertilizer sources, provided that sufficient quantities is immediately applied after crop harvest and incorporated into the soils. Similarly, our earlier findings in pot experiments, where legume and maize residues were compared, indicated that residues of haricot bean and pigeon pea were better quality than the maize residue, based on maize plant growth and nitrogen nutrient recovery (Abera et al. 2013).

\subsection{Relationship between soil moisture and mass loss, decomposition}

In site 3, when averaged over surface placed and subsoil buried, irrigation had evidently enhanced legume residue decomposition rates, perhaps through stimulating microbial activity. Hence, significantly greater residue decomposition was exhibited under irrigated than non-irrigated conditions (Fig. 4a). On average, residue decomposition rate was $100 \%$ greater in irrigated than in non-irrigated condition. In agreement with the present findings, higher rate of legume residue decomposition was exhibited under high $(\mathrm{pF} 2.5)$ than low (pF3.9) soil moisture contents under laboratory condition (Abera et al. 2012). Correspondingly, the $k$ values were significantly greater when residues were irrigated than nonirrigated (Fig. 4a).

Under non-irrigated condition, soil moisture effect appears to be important only during the beginning of litter decomposition, where the estimated decay rates for the first month are plotted against the soil moisture for the same period (data not shown). Thus, residue application should be performed at a time of sufficient moisture in order to save the cost of residue incorporation to soils and to optimize crop residue release of nutrients for subsequent crop. When inspecting the estimated $k$ values for the rest of the experimental period, other than first month (results not shown), we find significant positive correlations with moisture, but much weaker $\left(R^{2}\right.$ were 0.17 for haricot bean on surface, 0.13 for haricot bean subsurface placed, 0.14 for pigeon pea on surface, and 0.04 for pigeon pea subsurface); $p<0.05$ for all but pigeon pea subsurface. The regression functions suggest a weaker response to soil moisture than that for the initial decomposition rates. For instance, the regression function of haricot bean subsurface was $k=0.073+0.005 \times M$, where $k$ is the decay rate (in per month) and $M$ is the soil moisture (percentage of dry weight); similar responses to $M$ were found for the other treatments (0.004-0.007).

Overall, unexpected high microbial decomposition of legume residues were exhibited during the dry season in coffee and crop lands, implying high nutrient availability for subsequent crop. This suggests that at the early phase of residue decomposition, soil moisture is an essential factor possibly for facilitating the microbial colonization of the residues. On the other hand, the subsequent degradation is more robust to drought stress, once the microorganisms have colonized the litters. Similarly, Tian et al. (2007) indicated that the direct correlation between the decomposition rate of plant residues and moisture availability was only valid for plant residues with high quality. A recent study also revealed the dependence of respiration rates on changes in the precipitation and the resulting changes in the volumetric soil moisture explaining about $50 \%$ of the seasonal variability of respiration in Afromontane forest of southerneastern Ethiopia (Yohannes et al. 2011).

As stated earlier, we cannot exclude that some of the weight loss in our litterbags were caused by disintegration and particle losses due to invertebrate activity, or even active transport from the litterbags by such organisms. Furthermore, photodegradation may also have played a role in degrading the litter in the surface-placed litterbags, as Austin and Vivanco (2006) and Tian et al. (2007) found photodegradation to be a highly significant factor in the degradation of plant litter under semiarid tropical conditions. Both phenomena (invertebrates and photodegradation) could explain the relatively poor correlation between decomposition rates and soil moisture for the late phase of decomposition. This implies that litterbag method of decomposition and $\mathrm{N}$ mineralization studies has limitations and has to be used with cautions. For example, the size of the mesh, even when large, can exclude part of the macrofauna or can induce loss of material, and the litter confinement can modify the microclimatic conditions (Virzo De Santo et al. 1993). On the other hand, the 2-mm mesh size is supposed to be sufficiently small to prevent losses of litter caused by breakage, and to prevent the access of macrofaunal decomposers, such as worms and coleoptera (Salinas et al. 2011). Despite the controversy of it uses, this method is simple and inexpensive and is therefore widely used (Kurz-Besson et al. 2005). Furthermore, the present rapid decomposition of legume residues confirmed our earlier findings and has provided chance of exploring drought stress effect on litter decomposition under natural field condition. This simple and less expensive technique has confirmed our earlier laboratory and greenhouse pot experiment results (Abera et al. 2012; Abera et al. 2013), suggesting its usefulness in tropical condition.

\subsection{Carbon and $\mathrm{N}$ dynamics and $\mathrm{N}$ release from residues}

Residue mass and $\mathrm{C}$ losses followed similar patterns across sites. The residue $\mathrm{C}$ and $\mathrm{N}$ loss was moderately to strongly explained $\left(R^{2}=0.67-0.97, p<0.0001\right)$ by a single exponential model. Average $\mathrm{C}$ loss of 87 and $86 \%$ was displayed when surface applied with haricot bean and pigeon pea, respectively, across sites after 150 days of field incubation. Likewise, average C loss was 92 and $93 \%$ for haricot bean and pigeon pea, respectively when subsoil buried (Fig. 5a). This finding corroborates the $\mathrm{C}$ loss exhibited during laboratory incubation of the same tropical legume residues (Abera et al. 2012). 
Fig. 5 a-b Litterbag decomposition studies of carbon (a) and nitrogen (b) loss (\%) as affected by residue type and residue placement across seasonally dry agroecosystems in southern Ethiopia. Two legume residues, haricot bean, and pigeon pea along surface and subsurface placement were evaluated. The values are the average over four agroecosystems (sites)
Carbon loss (\%)

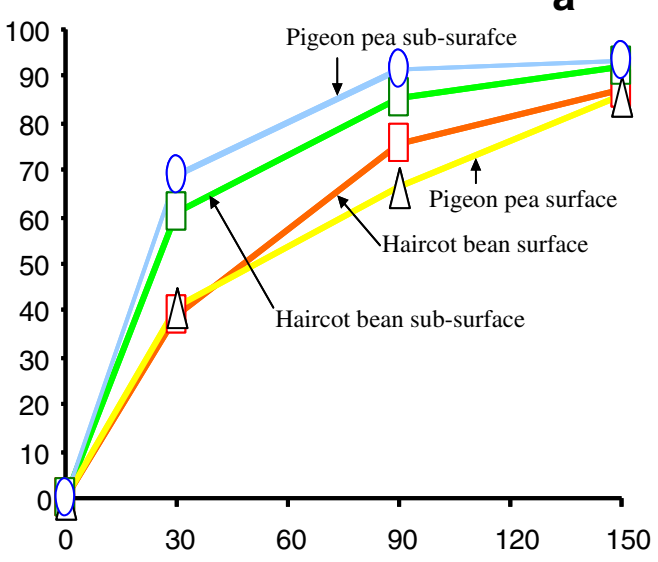

Nitrogen loss (\%)

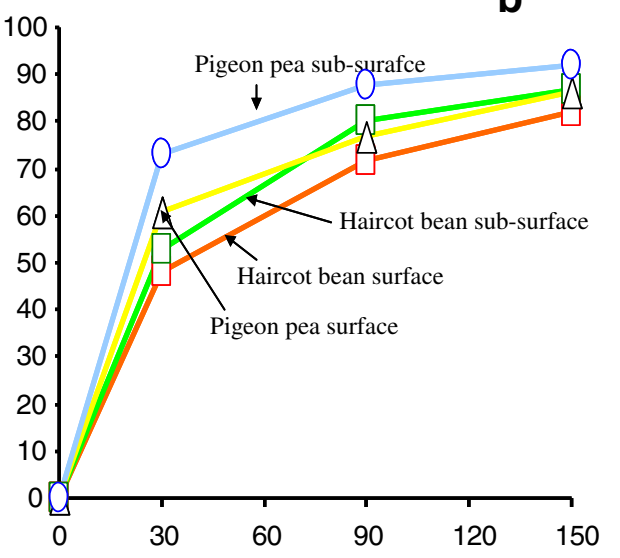

Sampling time (days)

The $\mathrm{N}$ loss after respective sampling day was relatively high in subsoil-buried residues as compared to the surface placed (Fig. 5b). Averaged over sites and residue placement, the initial $\mathrm{N}$ of haricot bean was declined by $85 \%$, while that of pigeon pea was decreased by $89 \%$, after 150 days of field litterbag setting. This could be attributed to high $\mathrm{N}$ and $\mathrm{P}$ concentrations, and low $\mathrm{C} / \mathrm{N}$ ratio of pigeon pea residue (Table 1), which are good indicators of the decomposition rates (Tateno et al. 2007; Abera et al. 2012). Nitrogen release pattern of the two legume residues followed similar trend with all sites throughout the litterbag experiment period. However, certain degree of $\mathrm{N}$ immobilization was noted when haricot bean was set in litterbag experiment with sites 1 and 4 soils (data not shown). This could be due to low initial $\mathrm{N}$ and $\mathrm{P}$ concentrations and high $\mathrm{C} / \mathrm{N}$ ratio of haricot bean residue (Austin and Viousek 2000; Tateno et al. 2007; Cusack et al. 2009; Abera et al. 2012).

A previous study indicated that up to $70 \%$ of $\mathrm{N}$ can be released from legume residue decomposition in temperate systems and higher amounts, under tropical conditions, during the first cropping season (Ehaliotis et al. 1998). Similarly, wide ranges of $\mathrm{N}$ released (21-68\%) from different legume species (Mucuna, Mucuna prurens; Lablab, Lablab purpureus; Sunhemp, Crotalaria juncea) in different tropical soils after 16 weeks of laboratory incubation were reported (Odhiambo 2010). In the present study, the amounts of $\mathrm{N}$ released under all conditions were greater than earlier reported values. More readily decomposable plant residues are often described as being of "high quality," when it contains $>2.5 \% \mathrm{~N},<15 \%$ lignin, and $<4 \%$ polyphenols as threshold (Palm et al. 2001). Though, lignin and polyphenols were not determined in the present study, based on initial $\mathrm{N}$ and $\mathrm{P}$ concentrations and $\mathrm{C} / \mathrm{N}$ ratio, pigeon pea can be considered a relatively better quality residue. Our observations confirm the previously reported pattern that the litter with high quality (characterized by higher
$\mathrm{N}$ concentration and lower $\mathrm{C} / \mathrm{N}$ ratio) can release $\mathrm{N}$ faster in comparison with low-quality litter (Palm et al. 2001; Abera et al. 2012).

\section{Conclusion}

The results revealed unexpected high microbial decomposition of legume residues in seasonal dry soils, implying substantial nutrient availability for subsequent crop. Soil moisture appears as an important regulator of the early decomposition through facilitating microbial colonization, whereas subsequent decomposition was robust to drought stress, once the microbial colonization was initiated. The $\mathrm{N}$ mineralization of the residues was 85 to $89 \%$ of their initial $\mathrm{N}$ content, indicating that larger proportion of $\mathrm{N}$ release due to legume residue decomposition within one season. Thus there was no significant difference in $\mathrm{N}$ release between haricot bean and pigeon pea implying that litter quality has less effect on $\mathrm{N}$ release, suggesting that other factors such as soil moisture, site and management factors might be more important. However, the litter quality should be considered with caution as the investigation did not include a contrast poor quality (cereal) residue. Subsoil burying showed $79 \%$ greater rates of residue decomposition than surface mulching across sites. Nevertheless, it is essential to note that incorporation of legume residue may not always necessary if there is sufficient moisture.

Acknowledgments We cordially acknowledge the Norwegian Program for Development, Research and Higher Education (NUFU) for funding this research work via legume-rhizobia collaborative project with Hawassa University. The laboratory facilities provided by the School of Plant and Horticultural Sciences of Hawassa University and the assistance offered by Mr. Solomon Yigerem and Samson Henta during the process of field establishment of the experiments and data generation are also duly acknowledged. 


\section{References}

Abera G, Wolde-meskel E, Bakken LR (2012) Carbon and nitrogen mineralization dynamics in different soils of the tropics amended with legume residues and contrasting soil moisture contents. Biol Fertil Soils 48:51-66. doi:10.1007/s00374-011-0607-8

Abera G, Wolde-meskel E, Bakken LR (2013) Effect of organic residue amendments and soil moisture on $\mathrm{N}$ mineralization, maize (Zea mays L.) dry biomass and nutrient concentration. Arch Agron Soil Sci. doi:10.1080/03650340.2012.722623

Adair EC, Patron WJ, Del Grosso SJ, Silver WL, Hall SA, Harmon ME, Hart SC (2008) A simple three pool model accurately describes patterns of long term, global decomposition in the Long-Term Intersite Decomposition Experiment Team (LIDET) data set. Glob Chang Biol 14:2636-2660. doi:10.1111/j.1365-2486.2008.01674.x

Anderson JM, Ingram JI (1993) Tropical soil biology and fertility-a handbook of methods, 2nd edn. CAB International, Wallingford

Arunachalam A, Singh ND (2004) Decomposition of Mesua ferrera litter in humid tropics Arunachal Pradesh, India. J Trop For Sci 16:151-159

Asgharipou MR, Rafiei M (2011) The effects of land use on biomass and catabolic diversity of soil microbial communities. Afr J Agric Res 6:4607-4612. doi:10.5897/AJAR11.1160

Austin AT, Viousek PM (2000) Precipitation, decomposition and litter decomposability of Metrosideros polymorpha in native forests on Hawai'i. J Ecol 88:129-138

Austin AT, Vivanco L (2006) Plant litter decomposition in a semi-arid ecosystem controlled by photodegradation. Nat Lett 442:555-558. doi:10.1038/nature05038

Borgen S, Molstad L, Bruun S, Breland TA, Bakken LR, Bleken MA (2011) Estimation of plant litter pools and decomposition-related parameters in a mechanistic model. Plant Soil 338:205-222. doi:10. 1007/s11104-010-0404-4

Coppens F, Garnier P, Findeling A, Merckx R, Recous S (2007) Decomposition of mulched versus incorporated crop residues: modelling with PASTIS clarifies interactions between residue quality and location. Soil Biol Biochem 39:2339-2350. doi:10.1016/j. soilbio.2007.04.005

Coûteaux M-M, Bottner P, Berg B (1995) Litter decomposition, climate and litter quality. Rev TREE 10:63-66

Cusack D, Chou W, Yang W, Harmon M, Silver W, the LIDET Team (2009) Controls on long-term root and leaf litter decomposition in Neotropical forests. Glob Chang Biol 15:1339-1355. doi:10.1111/j. 1365-2486.2008.01781.x

Dubeux JCB Jr, Sollenberger LE, Interrante SM, Vendramini JMB Jr, RLS (2006) Litter decomposition and mineralization in bahiagrass pastures managed at different intensities. Crop Sci 46:1305-1310. doi: $10.2135 /$ cropsci2005.08-0263

Ehaliotis C, Cadisch G, Giller KE (1998) Substrate amendments can alter microbial dynamics and $\mathrm{N}$ availability from maize residues to subsequent crops. Soil Biol Biochem 30:1281-1292

FAO (1998) World Reference Base for Soil Resources. World Soil Resources Reports 84. Food and Agricultural Organization of the United Nations, Rome

Henriksen TM, Breland TA (2002) Carbon mineralization, fungal and bacterial growth, and enzyme activities as affected by contact between crop residues and soil. Biol Fertil Soils 35:41-48. doi:10. 1007/s00374-001-0438-0

Kurz-Besson C, Coûteaux M-M, Thie'ry JM, Berg B, Remacl J (2005) A comparison of litterbag and direct observation methods of Scots pine needle decomposition measurement. Soil Biol Biochem 3:23152318. doi:10.1016/j.soilbio.2005.03.022

Landon JR (1991) Booker tropical soil manual: a handbook for soil survey and agricultural land evaluation in the tropics and subtropics. Longman, London, p 532

Magid J, De Neergaard A, Brant M (2006) Heterogeneous distribution may substantially decrease initial decomposition, long-term microbial growth and $\mathrm{N}$-immobilization from high $\mathrm{C}-\mathrm{N}$ ratio resources. Eur J Soil Sci 57:517-529

Odhiambo JJO (2010) Decomposition and nitrogen release by green manure legume residues in different soil types. Afr J Agric Res 5:090-096. doi:10.5897/AJAR09.489

Palm CA, Gachengo CN, Delve RJ, Cadisch G, Giller KE (2001) Organic inputs for soil fertility management in tropical agro-ecosystems: application of an organic resource database. Agric Ecosyst Environ 83:27-42

Pouyat RV, Carreiro MM (2003) Controls on mass loss and nitrogen dynamics of oak leaf litter along an urban-rural land-use gradient. Oecologia 135:288-298. doi:10.1007/s00442- 003-1190-y

Sakala WD, Cadisch G, Giller KE (2000) Interactions between residues of maize and pigeon pea and mineral $\mathrm{N}$ fertilizers during decomposition and N mineralization. Soil Biol Biochem 32:679-688

Salinas N, Malhi Y, Meir P, Silman M, Cuesta RR, Huaman J, Salinas D, Huaman V, Gibaja A, Mamani M, Farfan F (2011) The sensitivity of tropical leaf litter decomposition to temperature: results from a largescale leaf translocation experiment along an elevation gradient in Peruvian forests. New Phytol 189:967-977. doi:10.1111/j.14698137.2010.03521.x

Sierra J (2002) Nitrogen mineralization and nitrification in a tropical soil: effects of fluctuating temperature conditions. Soil Biol Biochem 34:1219-1226

Singh KP, Singh PK, Tripathi SK (1999) Litter fall, litter decomposition and nutrient release patterns in four native tree species raised on coal mine spoil at Singrauli, India. Biol Fertil Soils 29:371-378

Tateno R, Tokuchi N, Yamanaka N, Du S, Otsuki K, Shimamura T, Xu Z, Wang S, Hou Q (2007) Comparison of leaf litter production and leaf litter decomposition between an exotic black locust plantation and an indigenous oak forest near Yan'an on the Loess Plateau, China. Forest Ecol Manage 24:84-90. doi:10.1016/j.foreco.2006.12.026

Teklay T (2007) Decomposition and nutrient release from pruning residues of two indigenous agroforestry species during the wet and dry seasons. Nutr Cycl Agroecosyst 77:115-126. doi:10.1007/s10705-006-9048-4

Tian G, Badeji MA, Okoh AI, Ishida F, Kolawole GO, Hayashi Y, Salako FK (2007) Effect of residue quality and climate on plant residue decomposition and nutrient release along the transect from humid forest to Sahel of West Africa. Biogeochemistry 86:217-229. doi:10. 1007/s10533-007-9158-3

Virzo De Santo A, Berg B, Rutigliano FA, Alfani A, Fioretto A (1993) Factors regulating early-stage decomposition of needle litters in five different coniferous forests. Soil Biol Biochem 25:1423-1433

Yohannes Y, Shibistova O, Abate A, Fetene M, Guggenberger G (2011) Soil $\mathrm{CO}_{2}$ efflux in an Afromontane forest of Ethiopia as driven by seasonality and tree species. Forest Ecol Manage 261:1090-1098. doi:10.1016/j.foreco.2010.12.03

Zeng DH, Mao R, Chang SX, Li LJ, Yang D (2010) Carbon mineralization of tree leaf litter and crop residues from poplar-based agroforestry systems in Northeast China: a laboratory study. Appl Soil Ecol 44:133-137. doi:10.1016/j.apsoil.2009.11.002

Zhang D, Hui D, Luo Y, Zhou G (2008) Rates of litter decomposition in terrestrial ecosystems: global patterns and controlling factors. J Plant Ecol 1:85-93. doi:10.1093/jpe/rtn002 